\title{
Effect of different rates of inorganic fertilizer on physiology, growth and yield of okra (Abelmoschus esculentus) cultivated on BRIS soil of Terengganu, Malaysia
}

\author{
Mohammad Moneruzzaman Khandaker*, Fadhilah Nor M, Tahir Dalorima, Mohammad Hailmi \\ Sajili, Nashriyah Mat
}

School of Agriculture Science \& Biotechnology, Faculty of Bioresources and Food Industry, Universiti Sultan Zainal Abidin (UniSZA), Besut Campus, 22200 Besut, Terengganu, Malaysia

*Corresponding author: moneruzzaman@unisza.edu.my

\begin{abstract}
This study was designed to observe the effects of different application rates of inorganic fertilizers on growth, yield and quality of okra (Abelmoschus esculentus L. Moench) under BRIS soil condition. The field experiment was conducted during July, 2014 to April, 2015 at the teaching and research farm of University Sultan Zainal Abidin (UniSZA), Besut Campus, Terengganu. Performance of okra variety Singa 979 was assessed by application of NPK at different rates $\left(0 \mathrm{~kg} \mathrm{ha}^{-1}\right.$ (control), $150 \mathrm{~kg} \mathrm{ha}{ }^{-1}, 170 \mathrm{~kg}$ $\mathrm{ha}^{-1}, 190 \mathrm{~kg} \mathrm{ha}^{-1}$ and $210 \mathrm{~kg} \mathrm{ha}^{-1}$. The treatments were fitted in a randomized complete block design (RCBD) replicated thrice. Data collected for growth and yields performances included plant height, number of leaf/plant, leaf area, number of branch/plant, chlorophyll content, photosynthesis rate, transpiration rate, internal $\mathrm{CO}_{2}$, stomatal conductance, number of flower/plant, number of pod/plant, weight of pod, number of seed/pod and total soluble solid (TSS) of the pods. Based on the results obtained from this experiment, application of NPK at the rates of $190 \mathrm{~kg} \mathrm{ha}^{-1}$ and $210 \mathrm{~kg} \mathrm{ha}^{-1}$ shows the highest growth and yield performance. It is followed by application of $170 \mathrm{~kg} \mathrm{ha}^{-1}$ and $150 \mathrm{~kg} \mathrm{NPK} / \mathrm{ha}^{-1}$ in decreasing manner. No application of NPK shows the lowest growth and yield response. The significance of this research was to study the minimum rate of NPK on the effect on okra ground around the sea shore of Terengganu or in BRIS soil
\end{abstract}

Keywords: Abelmoschus esculentus, inorganic fertilizer, rates, growth, yield.

\section{Introduction}

Abelmoschus esculentus is cultivated throughout the tropical and warm temperate regions of the world for its fibrous fruits or pods containing round, white seeds. In the Middle East it is known as bamia, bamya or bamieh and gumbo in the Southern USA, and lady's finger in England. It is an erect herbaceous annual crop species that belongs to the family Malvaceae. Okra is a tall herb that is cultivated for its edible and immature pods. The pods help to neutralize acid substances which cause indigestion of meat and other food. The fruits are used in making soup, salad and for flavouring when dried and powdered. An understanding on soil chemical properties is essential especially in agriculture because of their effect on nutrient availability to plants. Nowadays, soil chemical properties and composition can be favorably altered with the use of lime and fertilizer materials. Most plants need 18 elements for normal growth and completion of their life cycle. These 18 elements are called the essential plant nutrients. Recently, soil amendments which containing the essential plant nutrients have been developed and used to enhance plant nutrition for better growth cycle.

Crop productivity in terms of responses to the fertilizer application can only be sustained if soil fertility levels are maintained to match with crops' requirement and in a proper rate (Jagadeeswaran et al., 2005). It is suggested that the use of chemical fertilizer has long-term negative effects to the soil properties and fertility (Akpan-Idiok et al., 2012).
However, organic manure is usually required in large quantity to sustain crop production and likely may not be available in small proportion for the small-scale farmers (Nyathi and Campbell, 1995). Besides that, organic manure is a slow releasing nutrient. The application of inorganic fertilizers at required rates gives a positive effect on crop yields and enhances yield improvement in agriculture food production (Akande et al., 2010).

Among 18 essential plant nutrients, nitrogen $(\mathrm{N})$, phosphorus $(\mathrm{P})$ and potassium $(\mathrm{K})$ are the most important nutrient and referred to as primary nutrients. The reason is because they are required by the plant in relatively large amounts compared to other nutrients. Aside from that, they are the nutrients that are most likely to be found to be limiting plant growth and development in soil systems if not available in adequate amount. In the commercial fertilizer, the ratio stated on the packaging bag refers to amount of an element is in the material (the guaranteed minimum quantity present) based on percentage by weight. All fertilizers are labelled with three numbers which give the percentage by weight of total nitrogen $(\mathrm{N})$, citrate-soluble phosphorus (expressed as $\mathrm{P}_{2} \mathrm{O}_{5}$ ) and water-soluble potassium (expressed as $\mathrm{K}_{2} \mathrm{O}$ ), respectively. Makinde and Ayoola (2008) reported that maize (Zea mays $L$.) yields obtained from application of a combination of synthetic fertilizer improved yield over that from manure alone. Akande et al. (2003) reported that the use of phosphate significantly improved growth and yield of 
Okra (Abelmoschus esculentus L Moench) compared to application of each material separately. Akanbi et al. (2005) reported that the combined application of $4 \mathrm{Mt} \cdot \mathrm{ha}-1$ of maize straw compost and $\mathrm{N}$ mineral fertilizer at $30 \mathrm{~kg} \cdot \mathrm{ha}-1$ improved plant growth and gave higher tomato (Lycopersicum esculentum). Okra requires nutrients such as nitrogen $(\mathrm{N})$, phosphorus $(\mathrm{P})$, potassium $(\mathrm{K})$, calcium $(\mathrm{Ca})$, sodium $(\mathrm{Na})$ and Sulphur $(\mathrm{S})$ for fertility maintenance and crop production. These nutrients are specific in function and must be supplied to plants at the right quantity. Lack of sufficient amounts of these nutrients result in poor performance of the crop with growth been affected resulting to low yield (Shukla and Naik, 2003).

Okra plants respond well to fertilizer in terms of vegetative growth. Yet, okra plants do not tolerate over fertilization neither lack of fertilizer retards growth of okra plants. Lack of fertilizer and over fertilizing will give a negative effect on the growth of okra plant. It will further affect the yield produce by the plant. The rapid leaching of inorganic fertilizers into the sea is a serious problem to the environment and the organisms living in the sea, and also the use of inorganic fertilizers is too expensive to be ignored, thus, this study intends to provide an alternative method by determining proper fertilizer rate for optimum growth and yield on okra crop.

\section{Results and Discussion}

\section{Effects of NPK rates on plant height}

Plant height is an importance character directly linked with the biomass accumulation and fruit yield. Okra plant height for each treatment was recorded and the data presented in Table 1. From the fig, it shows that there was a significant differences for plant height observed under application of different rates of NPK fertilizer. Plant height in NPK application of $190 \mathrm{~kg} \mathrm{ha}^{-1}$ shows the highest plant height while control, with no NPK application, gives the shortest okra plant. This shows that application of NPK fertilizer helps to improve growth of okra crops. Nitrogen, phosphorus, and potassium contained in the inorganic fertilizer have great effects in plant growth and development. These results are similar with the findings of Brown et al. (1995), who reported that the growth of okra plant was markedly influenced by the application of NPK fertilizer, as it was observed from the increased plant height and number of leaves compared to the control. The low response of okra to NPK fertilizer as compared to combined application of the two fertilizers is in agreement with the response patterns reported by other researchers on okra (Akanbi et al., 2005)

Plant need high concentration of this primary nutrient as any deficiency of the essential nutrients will prevent good plant growth (Gholizadeh et al., 2009). Within the stem resides the cambium where cell division takes place for a growing plant. Stems cannot widen or lengthen without phosphorus element that plays an important role in cell division which leads to the increase in width and length of stem. Thus, sufficient phosphorus supplied by NPK fertilizer helps in producing sturdy and taller okra plant.

\section{Number of leaves per plant}

The number of leaves produced by the okra plants was presented in Table 1. As can be seen from Table 1, the number of leaves produced is significantly affected by the rate of NPK fertilizer application. The least number of leaves was from control okra plant. On the other hand, NPK fertilizer application of $190 \mathrm{~kg} \mathrm{ha}^{-1}$ and $210 \mathrm{~kg} \mathrm{ha}^{-1}$ produced the highest number of leaves. (Olaniyi, 2010) also stated that number of leaves of okra were increased as the applied NPK rate increased. Babatola et al. (2002) also stated that increasing level of NPK 20:10:10 was observed to increase number of leaves and yield of okra in okra under field condition.

\section{Leaf area}

Leaf area of okra plants from all five treatments was recorded and visualized as bar chart in Table 1. The graph of the effect of different rate of NPK fertilizer application on okra leaf area was statistically analyzed and proven significant with $\mathrm{p}$ $<0.05$. From the fig 3, the largest leaves area was recorded on treatments with higher NPK fertilizer application (170 $\mathrm{kg} / \mathrm{ha}, 190 \mathrm{~kg} / \mathrm{ha}$ and $210 \mathrm{~kg} / \mathrm{ha}$ ). The smallest leaf area was recorded from control plant followed by NPK application of $150 \mathrm{~kg} / \mathrm{ha}$ (Table 1). This was due to the role of nitrogen $(\mathrm{N})$ in NPK fertilizer which promotes leaves growth in plants. Emebiri (2002) also has stated that application of NPK fertilizers increase leaf area in okra. Our result showed that nitrogen application produced a significant effect on leaf area. This is due to the increased of cell number and cell size in young leaf. It is suggested that cytokinin may play a role in leaf elongation either cell division or cell elongation, as the increase of leaf area following fertilization may be due to an increase in availability cytokinin in the shoots, which is normally produced in root tips.

\section{Number of branch per plant}

The number of branches emerged from the main stem of okra plant was recorded and displayed as a bar chart in Table 1 . From the Table 1, it shows that there was a significant difference for number of branches observed under application of different rates of NPK fertilizer. The lowest number of branches was recorded from control plant with average of 3 branches per plant. Treatment 5 with NPK application of 210 $\mathrm{kg} / \mathrm{ha}$ gave the highest number of branches, which is 7 branches per plant. This finding is also in conformity with the work of Emebiri (2002) who reported that number of branches per plant increased by NPK fertilizer application. It has been also reported that nitrogen fertilizer up to $150 \mathrm{~kg} \mathrm{~N}$ $\mathrm{ha}^{-1}$ increased the number of branch of sweet pepper (Khan et al., 2010). It was also reported that phosphorus also influenced the plant growth by increasing the number of branch of plant.

\section{Chlorophyll content and photosynthesis rate}

Table 1 presenting the chlorophyll content measured from okra plant with different NPK application treatments. Meanwhile, the photosynthesis rate of okra plant was recorded and represented in Fig 1. Nitrogen is a chlorophyll component and is responsible in promoting vegetative growth and green coloration of plant foliage. Nitrogen involve in the formation of chlorophyll which leads to an effective photosynthesis process. Thus, the higher the chlorophyll content, the higher the photosynthesis rate of the plant. For plant chlorophyll content, Table 1 shows that NPK fertilizer application at rate of $18 \mathrm{~kg} / \mathrm{ha}$ and $210 \mathrm{~kg} / \mathrm{ha}$ displayed the highest chlorophyll content, followed by $170 \mathrm{~kg} / \mathrm{ha}$ and 150 $\mathrm{kg} / \mathrm{ha}$. Control, with NPK application $0 \mathrm{~kg} / \mathrm{ha}$, demonstrated the lowest chlorophyll content. As predicted, high chlorophyll content leads to more efficient photosynthesis 
Table 1. Effects of different rate of inorganic fertilizer on morpho-physiological characteristics and chlorophyll content of okra.

\begin{tabular}{lccccc}
\hline $\begin{array}{l}\text { Treatment } \\
\left(\mathrm{kgha}^{-1} \mathrm{NPK}\right)\end{array}$ & No. of leaves /plant & $\begin{array}{c}\text { Plant height } \\
(\mathrm{cm})\end{array}$ & $\begin{array}{c}\text { Leaf area } \\
\left(\mathrm{cm}^{2}\right)\end{array}$ & $\begin{array}{c}\text { No of branch/ } \\
\text { plant }\end{array}$ & $\begin{array}{c}\text { Chlorophyll } \\
\text { content (SPAD) }\end{array}$ \\
\hline 0 & $49 \mathrm{c}$ & $65 \mathrm{e}$ & $360 \mathrm{~b}$ & $3.0 \mathrm{~b}$ & $20 \mathrm{~d}$ \\
150 & $64 \mathrm{~b}$ & $90 \mathrm{~d}$ & $400 \mathrm{~b}$ & $4.3 \mathrm{ab}$ & $26 \mathrm{c}$ \\
170 & $59 \mathrm{~b}$ & $100 \mathrm{c}$ & $598 \mathrm{a}$ & $6.0 \mathrm{ab}$ & $31 \mathrm{~b}$ \\
190 & $79 \mathrm{a}$ & $120 \mathrm{a}$ & $570 \mathrm{a}$ & $6.0 \mathrm{ab}$ & $38 \mathrm{a}$ \\
210 & $80 \mathrm{a}$ & $105 \mathrm{~b}$ & $630 \mathrm{a}$ & $7.0 \mathrm{a}$ & $39 \mathrm{a}$ \\
\hline
\end{tabular}

All the data were mean of five replications. Bars indicates \pm S.E. Different letter in same column are significantly different at $5 \%$ level

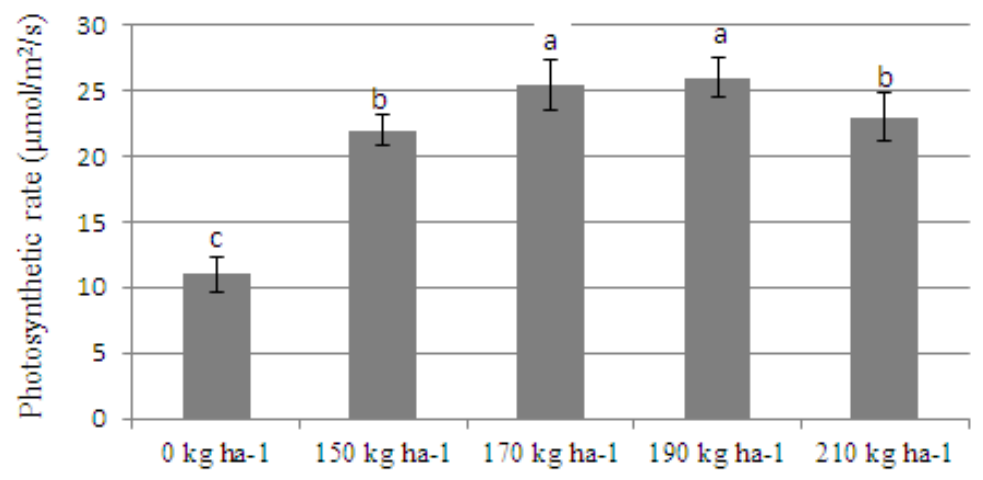

Treatment

Fig 1. The effect of different rates of NPK fertilizer on photosynthesis rate of okra. Bars indicate $( \pm$ S.E.) and presented with different alphabetic letters are significantly different $(\mathrm{p}<0.05)$.

Table 2. Effects of different rate of inorganic fertilizer on reproductive characteristics and TSS content of okra.

\begin{tabular}{llllll}
\hline $\begin{array}{l}\text { Treatment } \\
\left(\mathrm{kgha}^{-1} \mathrm{NPK}\right)\end{array}$ & No. of flower/plant & $\begin{array}{l}\text { No of pod } \\
\text { /plant }\end{array}$ & $\begin{array}{l}\text { Weight of pod } \\
(\mathrm{g})\end{array}$ & No of seed/pod & $\begin{array}{c}\text { Pod TSS content } \\
(\% \text { Brix })\end{array}$ \\
\hline 0 & $6.20 \mathrm{~b}$ & $8.00 \mathrm{c}$ & $16.5 \mathrm{c}$ & $60 \mathrm{c}$ & $1.8 \mathrm{c}$ \\
150 & $9.8 \mathrm{ab}$ & $11.5 \mathrm{bc}$ & $19.0 \mathrm{~b}$ & $85 \mathrm{a}$ & $2.4 \mathrm{bc}$ \\
170 & $10.3 \mathrm{ab}$ & $14.0 \mathrm{ab}$ & $19.0 \mathrm{~b}$ & $88 \mathrm{a}$ & $2.5 \mathrm{ab}$ \\
190 & $11.4 \mathrm{a}$ & $14.8 \mathrm{ab}$ & $27.0 \mathrm{a}$ & $70 \mathrm{~b}$ & $3.2 \mathrm{a}$ \\
210 & $11.8 \mathrm{a}$ & $15.7 \mathrm{a}$ & $18.0 \mathrm{~b}$ & $78 \mathrm{~b}$ & $2.5 \mathrm{ab}$ \\
\hline
\end{tabular}

All the data were mean of five replications. Bars indicates \pm S.E. Different letter in same column are significantly different at $5 \%$ level

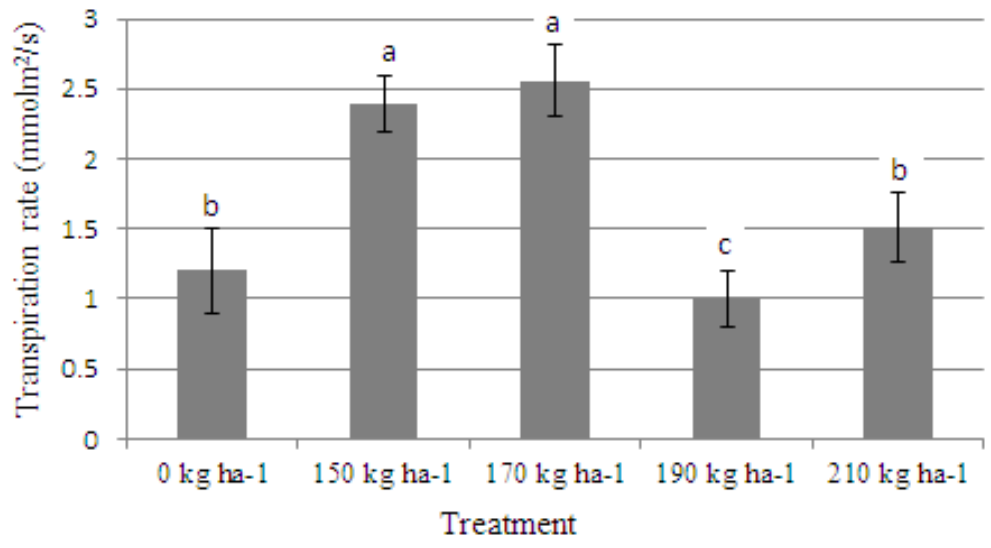

Fig 2. The effect of different rates of NPK fertilizer on transpiration rate of okra. Bars indicate $( \pm$ S.E.) and presented with different alphabetic letters are significantly different $(\mathrm{p}<0.05)$. 
Table 3. The initial physio-chemical properties of sandy BRIS soil used in the experiment.

\begin{tabular}{ll}
\hline Soil variable & Content \\
\hline Sand $(\%)$ & 96.4 \\
Silt $(\%)$ & 2.4 \\
Clay $(\%)$ & 1.2 \\
$\mathrm{pH}\left(\mathrm{H}_{2} \mathrm{O}\right)$ & 4.6 \\
$\left.\mathrm{CEC}\left[\mathrm{cmol}(+) \mathrm{kg}^{-1}\right)\right]$ & 9.64 \\
Organic carbon $(\%)$ & 0.44 \\
$\mathrm{~N}\left(\mathrm{~g} \mathrm{~kg}^{-1}\right)$ & 0.2 \\
$\mathrm{P}\left(\mathrm{g} \mathrm{kg}^{-1}\right)$ & 0.05 \\
$\mathrm{~K}\left(\mathrm{~g} \mathrm{~kg}^{-1}\right)$ & 0.09 \\
$\mathrm{Ca}\left(\mathrm{mg} \mathrm{kg}^{-1}\right)$ & 10.3 \\
$\mathrm{Mg}\left(\mathrm{mg} \mathrm{kg}^{-1}\right)$ & 7.6 \\
$\mathrm{Mn}\left(\mathrm{mg} \mathrm{kg}^{-1}\right)$ & 5.7 \\
$\mathrm{Cu}\left(\mathrm{mg} \mathrm{kg}^{-1}\right)$ & 4.9 \\
$\mathrm{Zn}\left(\mathrm{mg} \mathrm{kg}^{-1}\right)$ & 4.2 \\
\hline
\end{tabular}

Source: Hossain et al., (2011).

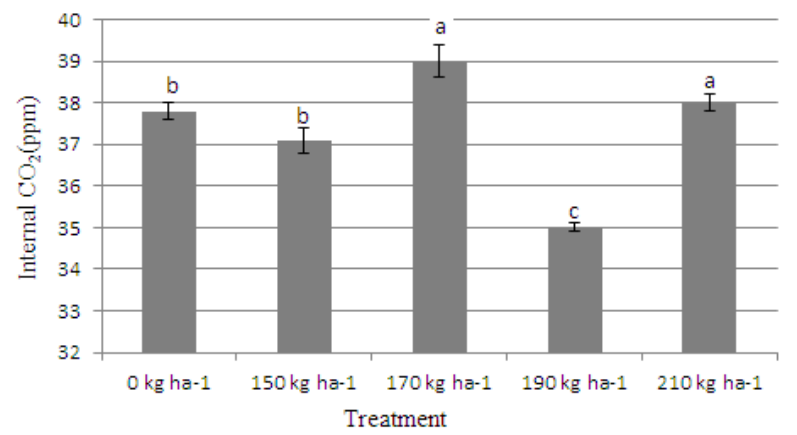

Fig 3. The effect of different rates of NPK fertilizer application on internal carbon dioxide $\left(\mathrm{CO}_{2}\right)$ of okra plant. Bars indicate $( \pm$ S.E. $)$ and presented with different alphabetic letters are significantly different $(\mathrm{p}<0.05)$.

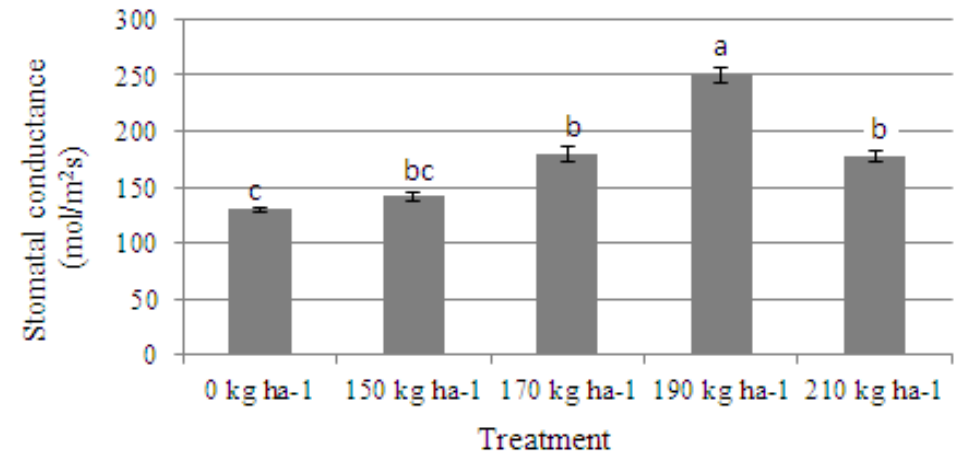

Fig 4. The effect of different rates of NPK on stomatal conductance of okra plant. Bars indicate $( \pm$ S.E) and presented with different alphabetic letters are significantly different $(\mathrm{p}<0.05)$.
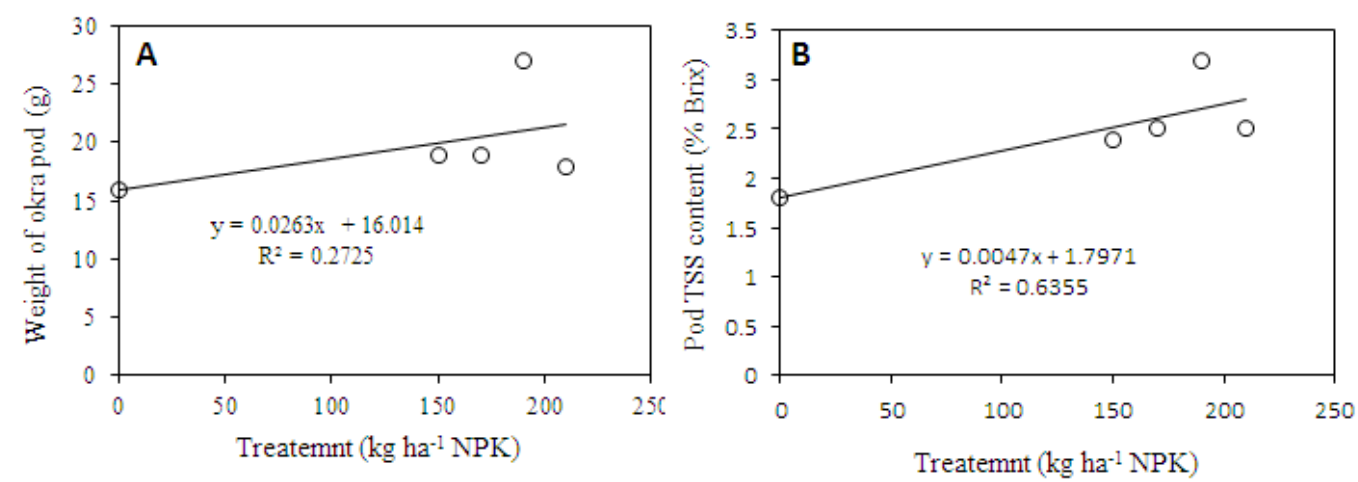

Fig 5. Correlation between fertilizer rate $\left(\mathrm{kg} \mathrm{ha}^{-1} \mathrm{NPK}\right)$ and weight of okra pod $(\mathrm{g})$ and pod TSS content (\% Brix). 


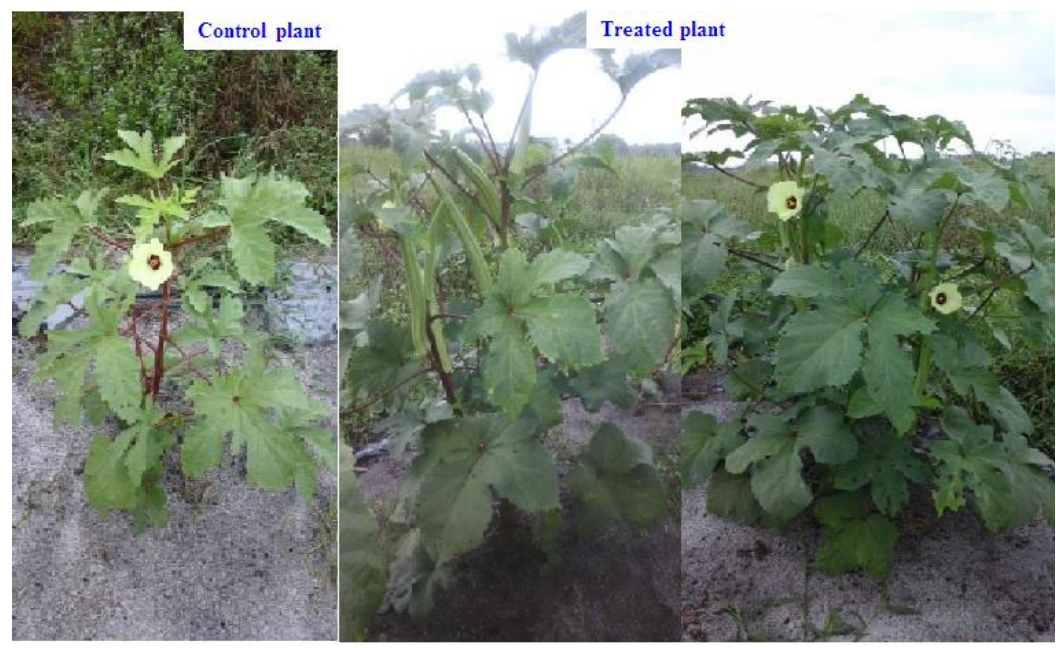

Fig 6. Photograph showing the okra plants control (no fertilizer) and treated with NPK fertilizer BRIS soil conditions.

activity in okra plant except for treatment with rate of 18 $\mathrm{kg} / \mathrm{ha}$ NPK application.

Leaf nitrogen plays a significant role in plant photosynthesis. Nitrogen application affects the net photosynthesis through by increased light interception. Nitrogen is essential component of rubisco as well as other protein and affect the size and morphology of chloroplast. From Fig 1, the highest photosynthesis rate was recorded in treatment with $170 \mathrm{~kg} / \mathrm{ha}$ and $210 \mathrm{~kg} / \mathrm{ha}$ NPK fertilizer application. Treatment $190 \mathrm{~kg} / \mathrm{ha}$ supposedly to have high photosynthesis activity since it has high chlorophyll content, but the photosynthesis rate recorded is low in this treatment. This might be due to other environmental factors such as disease which cannot be controlled since the experiment was carried out in field condition. Our results related to chlorophyll content and net photosynthesis are similar to the results of Yong et al (2010), who reported that foliar application of fertilizer increased the leaf chlorophyll content, $\mathrm{CO}_{2}$ assimilation rate and net photosynthesis of Jatropha plant. It has been also reported that the rate of photosynthesis increase due to appropriate nutrient application (Mandal and Sinha, 2004).

\section{Transpiration rate}

The transpiration rate of okra plants was recorded and presented in Fig 2. From the fig 2, it was clearly shown that the transpiration rate of okra plant was significantly affected by the application of NPK fertilizer. The highest transpiration rate was recorded from NPK treatment $170 \mathrm{~kg} / \mathrm{ha}$, followed by $150 \mathrm{~kg} / \mathrm{ha}, 210 \mathrm{~kg} / \mathrm{ha}$ and control. NPK treatment 190 $\mathrm{kg} / \mathrm{ha}$ showed the lowest transpiration rate. Plants require constant phosphorus level which is important in conversion of absorbed sunlight into usable energy, through transpiration and glycolysis process, for growth and reproduction. For control, some of P could be obtained from the soil so that control plants could convert some of its energy through transpiration. The increase in NPK rate supposedly promotes transpiration rate due to more usable energy availability. However, at high fertilizer treatment $190 \mathrm{~kg} / \mathrm{ha}$ and $210 \mathrm{~kg} / \mathrm{ha}$ decreased the transpiration rate in okra plant. Our results related to transpiration are showed in agreement with the findings of Zhu et al (2010), who reported that higher fertilizer dose reduced the transpiration rate of tomato plant. Similar results were also recorded in Brassica under potassium supply by Sharma et al. (1992) and in rice under water supply and water stress by Tiwari et al. (1998).

\section{Internal carbon dioxide ( $\left.\mathrm{CO}_{2}\right)$ and stomatal conductance}

Internal carbon dioxide $\left(\mathrm{CO}_{2}\right)$ of okra plant was recorded and visualized as bar chart in Fig 3. From the fig, it can be observed that there was a significant differences for internal carbon dioxide recorded under application of different rates of NPK fertilizer. The highest internal carbon dioxide $\left(\mathrm{CO}_{2}\right)$ was obtained from treatment $170 \mathrm{~kg} / \mathrm{ha}$ NPK fertilizer application, closely followed by $210 \mathrm{~kg} / \mathrm{ha}, 150 \mathrm{~kg} / \mathrm{ha}$ and control. Treatment $190 \mathrm{~kg} / \mathrm{ha}$ of NPK application show the lowest internal $\mathrm{CO}_{2}$ (Fig. 3). Carbon dioxide is important for okra plant as it is required in production of carbohydrates during photosynthesis process. Khandaker et al (2013b) reported that that stomatal conductance affects the net photosynthetic rate by regulating $\mathrm{CO}_{2}$ fixation in the leaf mesophyll tissue and is positively correlated with photosynthesis. The results showed that different dose of NPK fertilizer produced significant effect on the stomatal conductance of okra leaf. The highest stomatal conductance was recorded in $190 \mathrm{kgha}^{-1}$ treatment followed by 170 and $210 \mathrm{~kg} \mathrm{ha}^{-1}$ respectively. While okra plant without NPK treatment produced the lowest stomatal conductance (Fig. 4). Our findings shows an harmony with the results of $\mathrm{Xi}$ et al (1989), who reported that application of potassium fertilizer increased the stomatal conductance and decreased the transpiration rate of cotton

\section{Number of flowers and pods per plant}

The number of flowers produced by okra plant with different NPK application treatments is presented on fig 9. The pods production by okra plant was recorded and represented in Table 2. Table 2 shows that NPK fertilizer application significantly affected the flowers and pods production in okra plant. From the Table, both the numbers of flowers and pods increases with the increased in rate of NPK fertilizer application. The lowest number of flowers and pods was produced by control plant with no NPK fertilizer application. This finding was supported by (Somkuwar, 1997) who reported that pod yield increased with NPK fertilizer application. Yong et al (2010) also reported that fertilizer application increased the number of pods and seed number in pod of Jatropha plant. 


\section{Weight of pod}

Nitrogen fertilizer enhanced the vegetative growth, photosynthesis and accumulation assimilate of the plant. Besides, phosphorus stimulates cell division, elongation as well as flowering and fruit set. The weight of individual okra pod was recorded and converted as a bar chart in Table 2 . From the table, it shows that there was a significant difference for weight of pod measured under application of different rates of NPK fertilizer. The heaviest pod was obtained from treatment $18 \mathrm{~g} \mathrm{NPK/plant.} \mathrm{Our} \mathrm{results}$ supported by the findings of Babatola et al. (2002), who reported that application of inorganic fertilizer increased the number of pod and weight of pod under field conditions. The positive response of the pod yield to the NPK fertilizer application could be due to the synthesis of more assimilate that played significant role in flowering and increment of pod/fruit weight.

\section{Number of seeds per pod}

The number of seeds produced by individual pod was recorded and presented in Table 2. From the result obtained, it shows that NPK fertilizer application significantly affected the number of seeds produced in okra pod. The highest number of seeds obtained in okra plant that received NPK fertilizer of $150 \mathrm{~kg} \mathrm{ha}^{-1}$ and $170 \mathrm{~kg} \mathrm{ha}^{-1}$. The lowest seeds production was obtained from okra plant with no NPK fertilizer application (control). Based on the results obtained, NPK fertilizers of $150 \mathrm{kgha}^{-1}$ and $170 \mathrm{kgha}^{-1}$ were more suitable for seeds production (Table 2) but reduced the seed production. It was also observed that medium and higher rate of inorganic fertilizer 190 and $210 \mathrm{kgha}^{-1}$ NPK decreased the seed production of okra pod. Our results are supported by the findings of Andreasen et al (2014), who reported that higher concentration foliar fertilizer reduced the seed yield gerbera plant.

\section{Total soluble solids (TSS)}

The total soluble solids (TSS) of okra pods was recorded and presented in Table 2. From the result obtained, it shows that NPK fertilizer application significantly affected the total soluble solid in okra pod. The highest TSS was obtained from okra pod harvested from plant that received $190 \mathrm{~kg} \mathrm{NPK} / \mathrm{ha}^{-1}$, with percentage Brix of 3.07. The lowest percentage Brix is 1.77 which was recorded from control plants. Potassium from NPK fertilizer plays a role in increasing Brix percentage by increasing the accumulation of photosynthates in okra pod. Similar amount of TSS content also reported by Khandaker et al (2017), who reported that different dose of organic fertilizer increased the TSS content of okra pod.

Correlation between fertilizer rate with pod weight and TSS content

As can be shown from Figure 5, okra pod weight with fertilizer dose up to $190 \mathrm{~kg} \mathrm{ha}^{-1}$ and thereafter pod weight decreased with higher dose of NPK fertilizer. May be higher doses of NPK fertilizer cause drop of leaf drop of okra and reduce the quality of okra pod. This results supported by the findings of Wrona (2004), who reported that higher doses of nitrogen fertilizer reduced the number of fruit, fruit weight and quality of fruits. We recorded here week correlation between pod weight and fertilizer dose. Similarly, in this study a medium correlation was found between fertilizer dose and TSS content of okra pod. Khandaker et al. (2013a) also reported that intercultural operations viz; nutrient management, plant growth regulators application and phloemic stress increase the TSS content fruit. TSS content increased at medium dose $\left(150-190 \mathrm{~kg} \mathrm{ha}^{-1}\right)$ but decreased at $210 \mathrm{~kg} \mathrm{ha}^{-1}$ treatment (Figure 5). Treatment that gives the best result on growth performance and yield of okra is treatment with NPK application $190 \mathrm{kgha}^{-1}$ and $210 \mathrm{kgha}^{-1}$. This finding is in conformity with that of (Babatola and Olaniyi, 1999) who reported that the application of higher rate of NPK enhanced the growth and yield of okra.

\section{Materials and Methods}

\section{Plant materials}

This study was conducted in the teaching and research farm of the faculty of Bio-resources and Food industry, University Sultan Zainal Abidin, Besut Campus, Terengganu. Seeds of okra (Abelmoschus esculentus L. Moench var. singa) germinate in trays with peat moss as germination media. Chicken dung and organic matter biochar were applied to the field for improve water holding capacity and other physical properties. Inorganic fertilizer Nitrogen $(\mathrm{N})$, citrate-soluble phosphorus (expressed as $\mathrm{P}_{2} \mathrm{O}_{5}$ ) and water-soluble potassium $\left(\mathrm{K}_{2} \mathrm{O}\right)$ (with the ratio 12:12:17) were used for the study.

\section{Treatment setting}

Beds were prepared by ploughing the BRIS soil first. In BRIS soil sand percentage is more than $90 \%$ (Table 3 ). Then, the soil was mixed with biochar of chicken dung at $300 \mathrm{~kg}$ ha ${ }^{1}$ to enhance the humus and organic content in the soil. The land was ploughed two weeks before the bed making for planting of okra seeds. The area of land used was 0.012 ha. This plot of land was divided into three replicates, each containing 5 beds to give a total of 15 experimental units. Each bed size was $1.2 \mathrm{~m} \times 1.2 \mathrm{~m}$ with $0.5 \mathrm{~m}$ spacing between beds and $1 \mathrm{~m}$ apart in each block of rows for easy movement during cultural operations. The seeds were planted at a spacing of $0.5 \mathrm{~m} \times 0.5 \mathrm{~m}$ to give a total of 40,000 plants ha ${ }^{-1}$. The treatments used include five (5) levels of NPK $(0,150$, 170, 190 and $\left.210 \mathrm{~kg} \mathrm{NPK} \mathrm{ha}{ }^{-1}\right)$. The various fertilizer treatments were applied three week after planting. Cultural operations such as weeding and irrigation were carried out at two weeks intervals from the beginning. The seedling was irrigated 2 times per day, during early in the morning and at late evening.

\section{Treatment application and experimental design}

There are five treatments which comprises of different rates of NPK fertilizer application. The rate of NPK fertilizer that was applied for each treatment; T0 act as control at which there is no NPK fertilizer applied; (T1), 150; (T2), 170; (T3), 190 and (T4), 210 NPK kgha ${ }^{-1}$. The treatments were applied every 2 weeks starting from day 0 after transplanting until week 11 after transplanting. The experiment was done using a Randomized Completely Block Design (RCBD) layout with three replicates. Each replicate consist of 10 plants of each treatment. Total number of plant that was observed in the experiment is 150 plants ( 10 plants $\times 3$ replicates $\times 5$ treatments). The 5 treatments were randomised in each replication.

\section{Morpho-physiological parameters: Plant height, number leaves, leaf area and branch per plant}

Plant height was measured starting from the base of the stem to the tip of the highest leaf by using ruler or measuring tape. 
The unit used for plant height measurement is centimeter $(\mathrm{cm})$. This was accomplished by manual observation where the number of leaves per plant was counted. Firstly, both the length and width of the selected leaf was measured using ruler. The leaf area was determined by multiplying both the length and the width of the leaf. The unit used for leaf area is $\mathrm{cm}^{2}$. This parameter was taken by manual observation where the number of branch emerged from the main stem of the okra plant was counted.

\section{Chlorophyll content, Photosynthesis rate, transpiration rate, internal $\mathrm{CO}_{2}$ and stomatal conductance}

The SPAD chlorophyll meter was required to determine the chlorophyll content in leaves. The reading was taken when there is no moisture attached to the leaves surface to avoid false data. Photosynthesis data were recorded from 11 am to $2 \mathrm{pm}$ once a week immediately after treatment application. Net photosynthesis rate, transpiration rate and internal $\mathrm{CO}_{2}$ of okra plant were taken by using CI-340 Handheld Photosynthesis System (CID Bio-Science, USA). Net photosynthetic rate was expressed as $\mu \mathrm{mol} / \mathrm{m}^{2} / \mathrm{s}$. Leaf stomatal conductance of okra plant was measured using a portable leaf porometer (Model SC-1, USA). A leaf chamber was attached to one leaf of okra and kept the leaf at an ambient temperature for $10-15$ mins to maintain sunlight adaptation. Leaf stomatal conductance was measured from three different spot of a single leaf.

\section{Number of flowers and pods per plant}

This parameter was taken through weekly manual observation where the total number of flowers produced by the okra plant was counted throughout 11 weeks after field transplanting. This parameter also was taken by manual observation where the total number of pods produced by the okra plant was counted.

\section{Weight of pod, number of seeds and Total soluble solids (TSS)}

The edible pod of similar sizes from each treatment was harvested at immature stages. The weight of the individual pod was measured by using electronic weighing balance in gram unit. Number of seeds was determined manually by slicing the okra pod and counting all the seeds contained in the pod. Total soluble solids of okra pod were taken by using Refractometer Pal-3. The okra pod was first grinded by pastel and mortar until it was crushed. It was then placed in muslin cloth to squeeze out the mucilage from the crushed okra pod.

\section{Statistical analysis}

The data obtained was analysed statistically by using Oneway ANOVA in Statistical Package for Social Sciences Software 20.0 (SPSS version 20.0) with post-hoc analysis to detect the treatments effects on the plant growth. P value less than 0.05 was considered to be statistically significant. The mean differences were determined by using Microsoft Excel 2010.

\section{Conclusion}

From the overall results, treatment with NPK fertilizer application of $190 \mathrm{kgha}^{-1}$ gives the highest plant height, number of leaves, chlorophyll content, net photosynthesis, stomatal conductance, number of pods/plant, weight of pods and total soluble solids (TSS) content in pod. In addition, less transpiration rate, internal $\mathrm{CO}_{2}$ and fewer seed in pod were found with $190 \mathrm{~kg} \mathrm{ha}^{-1}$ NPK treatment. On the other hand, treatment $210 \mathrm{kgha}^{-1}$ NPK gives the largest leaf area and the highest number of leaves, branches, flowers, pods and number of seeds/pod. Control treatment shows the slowest growth rate and yield of okra plant. It can be concluded that application of $190 \mathrm{kgha}^{-1}$ NPK fertilizer under BRIS soil conditions had significantly improve the growth, yield and quality of okra plant.

\section{Acknowledgements}

The authors wish to thank the Research Management, Innovation \& Commercialization Centre (RMIC), University Sultan Zainal Abidin, Terengganu for publication support. We also highly indebted to En. Mohd. Rohaizad Md Rejab and Pn. Norhayati Mohd Zakaria for their guidance and permission to use all required equipment and the necessary materials needed for the project.

\section{References}

Akanbi WB, Akande MO, Adediran JA (2005) Suitability of composted maize straw and mineral nitrogen fertilizer for tomato production. J Veg Sci. 11 (1): 57-65.

Akande MO, Oluwatoyinbo FI, Makinde EA, Adepoju AS, Adepoju IS (2010) Response of okra to organic and inorganic fertilization. Nat Sci. 8(11): 261-266.

Akande MO, Oluwatoyinbo FI, Adediran JA, Buari KW, Yusuf IO, (2003) Soil amendments affect the release of $\mathrm{P}$ from rock phosphate and the development and yield of okra. J Veg Crop Prod. 9(2): 3-9.

Akpan-Idiok AU, Udo IA, Braide EI (2012) The use of human urine as an organic fertilizer in the production of okra (Abelmoschus esculentus) in south eastern nigeria. Resour Con Recy. 62:14-20.

Andreasen C, Hansen A, Kemezys, Müller R (2014) The effect of fertilizer level and foliar-applied calcium on seed production and germination of gerbera hybrid. HortSci. 49 (5):538-543.

Babatola LA, Ojo DO, Adewoyin OB (2002) Effect of NPK 20:10:10 fertilizer levels on the yield of okra-sweetcorn intercrop and post harvest qualitynof okra. Proc Hort Soc Nigeria Conference, pp: 74-78.

Brown JE, Kovach SP, Goff WD, Himeirick DG, Tilt KM, Gazaway WS, Curtis LM, Tyson TW (1995) Fumigation and mulch affect yield, weight, and quality of 'Pimiento' pepper, Capsicum annuum L. J Veg Crop Prod. 1:71-80

Emebiri LC (2002) Growth yield and yield components responses of three okra cultivars (Abelmoschus esculentus L. Moench) to fertilization in the humid tropics, Acta Hort. 30(1). 47-58.

Gholizadeh A, Amin MSM, Anuar AR, Aimrun W (2009) Evaluation of SPAD chlorophyll meter in two different rice stages and its temporal variability, European J Sci Res. 37(4): 591-598.

Hossain MD, Hanafi MM, Jol H, Hazandy AH (2011) Growth, yield and fiber morphology of kenaf Hibiscus cannabinus $\mathrm{L}$.) grown on sandy bris soil as influenced by different levels of carbon. Afr J Biotechnol. 10(50): 10087-10094.

Jagadeeswaran R, Murugappan V, Govindaswamy M (2005) Effect of slow release NPK fertilizer Sources on the nutrient use Efficiency in turmeric. World J Agril Sci 1(1): 65-69. 
Khan H, Khan M, Rasul K, Majeed A, Safi FA (2010) Effect of different levels of nitrogen alone and in combination with constant doses of phosphorus and potassium on growth and yield of okra (Hibiscus esculentus L.) Cv. T-13 under Agro-climatic conditions of Mingora, Swat. Pak J Biol Sci 3(12):2101-2104

Khandaker MM, Jusoh N, Hafiza NAAR, Ismail SZ (2017) The effect of different types of organic fertilizers on growth and yield of Abelmoschus esculentus. moench (okra). Bulgarian J Agril Sci. 23 (1):119-125

Khandaker MM, Boyce AN, Normaniza O, Faruq G, Rahman MM, Sofian-Azirun M (2013a) Fruit development, pigmentation and biochemical properties of wax apple as affected by localized application of $\mathrm{GA}_{3}$. Braz Arc Biol Technol. 56(1):11-20.

Khandaker MM, Boyce AN, Normaniza O, Faruq G, Rahman MM, Sofian-Azirun M (2013b) The influence of 1triacontanol on the growth, flowering, and quality of potted Bougainvillea plants (Bougainvillea glabra var. "elizabeth angus"') under natural conditions. Sci World J. v 2013, Article ID 308651:1-12.

Makinde EA, Ayoola AA (2008) Residual influence of early season crop fertilization. Amer J Agric Biol Sci. 3(4):712715.

Mandal KG, Sinha AC (2004) Nutrient management effects on light Interception, photosynthesis, growth, dry-matter production and yield of indian mustard (Brassica juncea). J Agron Crop Sci. 190: 119-129.

Nyathi P, Campbell BM (1995) Interaction effect of tree leaf litter, manure and inorganic fertilizer on the performance of maize in zimbabwe. Afr Crop Sci J. 3(4): 451-456.
Olaniyi JO, Akanbi WB, Olaniran OA, Ilupeju OT (2010) The effect of organo-mineral and inorganic fertilizers on the growth, fruit yield, quality and chemical compositions of okra. J Animal Plant Sci. 9(1): 1135-1140.

Sharma KD, MS Kuhad, Nandwal AS (1992) Possible role of potassium in drought tolerance in Brassica $\mathrm{J}$ Potassium Res. 6: 320-327.

Shukla V, Nalk LB (2003) Agro technique for malvaceae vegetables, In: Ifovance in horticulture vol 5. Malhotra publishing house New Delhi India PP 399-425.

Somkuwar RG, Mahakal KG, Kale PB (1997) Effect of different levels of nitrogen on growth and yield in okra varieties. PKV Res J 21(2): 202-204.

Tiwari HS, Agarwal RM, Bhatt RK (1998) Photosynthesis, stomatal resistance and related characteristics as influenced by potassium under normal water supply and water stress conditions in rice (Oryza sativa L.). Indian J Plant Physiol. 3: 314-336

Wrona D (2004) Effect of nitrogen fertilization on growth, cropping and fruit quality of 'Šampion' apple trees during 9 years after planting. Folia Hort. 16(1): 55-60.

Xi S, Lihua R, Yongsong Z, Qizhao Y, Caixian T, Lianxiang Q (1989) Effect of potassium fertilizer application on physiological parameters and yield of cotton grown on a potassium deficient soil. J Plant Nutr Soil Sci. 152(3):269272

Yong JWH, NgS YF, TanA N, Chew YL (2010) Effect of fertilizer application on photosynthesis and oil yield of Jatropha curcas L. Photosynth. 48 (2): 208-218.

Zhu J, Liang Y, Zhu Y, Wanglin H, Lin X, Xing Wu, Luo A ( 2010) The interactive effects of water and fertilizer on photosynthetic capacity and yield in tomato plants. Aus J Crop Sci 6(2):200-209 